\title{
Nasljedna trombofilija
}

\section{Inherited thrombophilia}

\author{
Petra Baumgartner ${ }^{1}$, Toni Valković ${ }^{2 *}$
}

${ }^{1}$ Klinika za bolesti srca i krvnih žila, KBC Rijeka, Rijeka, Hrvatska

${ }^{2}$ Zavod za hematologiju, KBC Rijeka; Medicinski fakultet i Fakultet zdravstvenih studija Sveučilišta u Rijeci, Rijeka, Hrvatska

\section{"Dopisni autor:}

Prof. dr. sc. Toni Valković, dr. med. Zavod za hematologiju, KBC Rijeka, Krešimirova 42, 51000 Rijeka

E-mail: toni.valkovic@medri.uniri.hr

\section{http://hrcak.srce.hr/medicina}

Sažetak. Pojam trombofilija podrazumijeva nasljedne i/ili stečene poremećaje sustava zgrušavanja krvi koji predisponiraju razvoj tromboze. Nasljedna trombofilija obuhvaća stanja u kojima naslijeđene genetske mutacije dovode do abnormalne količine ili funkcije proteina uključenih u sustav koagulacije, što za posljedicu može imati povećanu sklonost venskim i, znatno rjeđe, arterijskim trombozama. Nedvojbeno definirana nasljedna trombofilna stanja nedostatak su antitrombina, proteina $\mathrm{C}$ i proteina $\mathrm{S}$ te pojava faktora $\mathrm{V}$ Leiden i protrombinskih varijanti. Još uvijek ne postoje jednoznačne preporuke za testiranje nasljedne trombofilije, a profilaksa i liječenje tromboembolijskih događaja moraju biti individualizirani.

Ključne riječi: antitrombin; faktor $\mathrm{V}$ Leiden; nasljedna trombofilija; protein $\mathrm{C}$; protein $\mathrm{S}$; protrombinska varijanta; tromboembolijski incidenti

Abstract. The term thrombophilia implies inherited and/or acquired disorders of the hemostasis mechanism that predispose to the development of thrombosis. Inherited thrombophilia includes conditions in which an inherited genetic mutations affect the amount or function of proteins involved in the coagulation system, and as a consequence, an increased tendency to venous and, much less frequently, arterial thrombosis. Undoubtedly defined inherited thrombophilic conditions are the deficiency of antithrombin, protein $\mathrm{C}$ and protein $\mathrm{S}$ and the appearance of factor $\mathrm{V}$ Leiden and rothrombin's variants. There is still no clear recommendation for testing hereditary thrombophilia, and the prophylaxis and the treatment of thromboembolic events must be individualized.

Key words: antithrombin; factor $\mathrm{V}$ Leiden; inherited thrombophilia; protein C; protein S; prothrombin variant; thromboembolic events

Napomena: Ovaj tekst je dorađeni dio diplomskog rada "Urođene trombofilije“ Petre Baumgartner, dr. med., koji je izrađen i obranjen na Zavodu za hematologiju Klinike za internu medicinu Kliničkog bolničkog centra Rijeka te Katedri za internu medicinu Medicinskog fakulteta Sveučilišta u Rijeci, pod mentorstvom prof. dr. sc. Tonija Valkovića, dr. med. 


\section{UVOD}

U fiziološkim uvjetima postoji homeostaza između čimbenika koji potiču zgrušavanje krvi i onih koji sprječavaju koagulaciju, no cijeli niz stečenih i nasljednih poremećaja može poremetiti ovu ravnotežu, što za posljedicu može imati pojačanu sklonosti krvarenju ili zgrušavanju krvi. Pojam trombofilija predstavlja pojačanu sklonost zgrušavanju krvi, što dovodi do češće pojave tromboza i tromboembolija.

Trombofilija može biti primarna (nasljedna/urođena) ili sekundarna (stečena) ${ }^{1}$. U primarne se ubrajaju prirođeni, najčešće nasljedni, kvantitativni ili kvalitativni defekti prokoagulantnih ili antikoagulantnih proteina, a sekundarne trombofilije čine stečena stanja koja povećavaju sklonost zgrušavanju, kao npr. trudnoća, trauma, dugotrajna imobilizacija, zloćudne bolesti, neka specifična

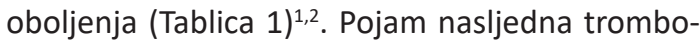
filija obuhvaća stanja u kojima naslijeđena genska mutacija utječe na količinu ili funkciju proteina uključenog u sustav koagulacije, a kao posljedica nastaje povećana sklonost venskim i rjeđe arterijskim trombozama ${ }^{3}$. Mutacije koje dovode do gubitka funkcije pojedinih proteina uključuju one koje zahvaćaju gene koji kodiraju antitrombina $(A T)$, proteina $C(P C)$ i proteina S (PS). Suprotno njima, mutacije gena za faktor $\mathrm{V}$ i gena za protrombin dovode do pretjerane aktivnosti navedenih faktora zgrušavanja ${ }^{4}$. Pojam trombofilija javlja se u medicinskoj literaturi još prije 2. svjetskog rata kada je opisano pet slučajeva s rekurentnim trombozama velikih i malih krvnih žila u ekstremitetima, bubrezima, srcu i mozgu, pa se od tada nadalje u literaturi postupno opisuju i drugi slučajevi obiteljske sklonosti trombotskim događajima te se kasnije ti slučajevi patogenetski razjašnjavaju utvrđujući konkretni genetski uzrok poremeća$\mathrm{ja}^{5}$. U ovom kratkom preglednom članku zbog svoje specifičnosti i opsežnosti ne obrađuje se tema nasljedne trombofilije i trudnoće.

Genske varijacije poput Faktor V Leiden i protrombinske varijante, nedostatak proteina $\mathrm{C}$, proteina $\mathrm{S}$ i antitrombina povećavaju rizik od razvoja venskog tromboembolizma, no sami poremećaji karakterizirani su varijabilnom ekspresivnošću i nepotpunom penetrabilnošću. Uz to sama predispozicija za stvaranje ugrušaka najčešće proizlazi iz interakcije između genetičkih i stečenih čimbenika.

\section{EPIDEMIOLOGIJA}

Epidemiološke studije pokazale su povećan rizik za duboku vensku trombozu (DVT) i plućnu tromboemboliju (PTE) u pacijenata $s$ nasljednom trombofilijom, no oni se najčešće otkrivaju tek nakon osobnog ili obiteljskog tromboembolijskog incidenta. Stvarnu učestalost nasljedne trombofilije vrlo je teško precizno odrediti ${ }^{4}$. Postoje podaci o prevalenciji nasljedne trombofilije u simptomatskoj populaciji, tj. osobama koje su

Tablica 1. Sekundarni (stečeni) uzroci mogućeg hiperkoagulabilnog stanja

\begin{tabular}{|l|l|}
\multicolumn{1}{|c|}{ BOLESTI } & \multicolumn{1}{c|}{ OSTALO } \\
\hline - solidne zloćudne bolesti & - dugotrajna imobilizacija \\
- hematološke novotvorine (posebno & - veći kirurški zahvati \\
mijeloproliferativne neoplazme i paroksizmalna & - traume \\
noćna hemoglobinurija) & - trudnoća \\
- - teže intifosfolipidni sindrom & - pušenje cigareta \\
- nefrotski sindrom & - dugotrajno putovanje avionom \\
- kongestivno srčano zatajenje & - dugotrajno stajanje \\
- bolesti praćene hiperviskoznošću & - oralna hormonalna kontracepcija \\
- upalna bolest crijeva & - hormonalna nadomjesna terapija \\
- kronične bolesti bubrega & - debljina \\
- varikoziteti vena & - fizička neaktivnost \\
- moždani udar & - lijekovi (npr. neki protutumorski lijekovi, \\
- vaskulitisi & antiepileptici i drugi) \\
\hline
\end{tabular}


Tablica 2 Najčešći uzroci nasljedne trombofilije i njihova prevalencija ${ }^{6}$

\begin{tabular}{|l|c|c|c|}
\hline \multirow{2}{*}{\multicolumn{1}{|c|}{ UZROK TROMBOFILIJE }} & \multicolumn{3}{|c|}{ PREVALENCIJA } \\
\cline { 2 - 4 } & OPĆA POPULACIJA & POPULACIJA S VTE-OM & TROMBOFILNE OBITELII \\
\hline Manjak antitrombina & $0.0002-0.002 \%$ & $1 \%$ & $4 \%$ \\
\hline Manjak proteina C & $0.2-0.4 \%$ & $3-5 \%$ & $6 \%$ \\
\hline Manjak proteina S & $0.03-0.13 \%$ & $1-5 \%$ & $6 \%$ \\
\hline Faktor V Leiden & $1-15 \%$ & $10-50 \%$ & $45 \%$ \\
\hline Protrombinska varijanta 20210A & $1-3 \%$ & $6 \%$ & $10 \%$ \\
\hline
\end{tabular}

imale tromboembolijske incidente, neke su studije provedene među asimptomatskim članovima obitelji s pozitivnom tromboembolijskom anamnezom, a postoji i nekoliko studija provedenih u općoj populaciji. Tablica 2. prikazuje najčešće nasljedne uzroke trombofilije i njihovu prevalenciju u općoj populaciji, populaciji koja je imala tromboembolijske incidente i trombofilnim obitelji$\mathrm{ma}^{6}$.

\section{POJEDINI UZROCI NASLJEDNE TROMBOFILIJE}

\section{Nasljedni manjak antitrombina}

lako je već na početku 20. stoljeća bila uočena sposobnost plazme da neutralizira trombinsku aktivnost, tek je 1963. dokazana prisutnosti AT-a u plazmi, a nedugo zatim, 1965. godine, Egeberg je izvijestio o deficijenciji AT-a u obitelji koja je imala više članova koji su bolovali od venske tromboze ${ }^{5}$. Također, on je pretpostavio da se bolest nasljeđuje autosomno dominantno ${ }^{5}$. AT se ubraja u alfa-2 globuline, sintetizira se uglavnom u jetri, ima poluživot od oko 2,4 dana, molekulska masa mu je 58200 Da i sadrži 432 aminokiseline. $\mathrm{U}$ krvi postoje dvije izoforme ovog proteina - A izoforma koja čini 90 - 95 \% i B izoforma koja čini samo 5 - $10 \%$ ukupnog AT-a i čija fiziološka uloga još nije posve razjašnjena7. AT je multifunkcionalni inhibitor brojnih enzima koagulacijskog puta ${ }^{8}$. Djeluje na faktor Ila, faktor Xa i u manjoj mjeri na faktore IXa, XIa, XIIa9. Sam po sebi AT je spor inhibitor, ali heparan sulfati te glikozaminoglikani prisutni na intaktnom endotelu izrazito potiču njegovo inhibicijsko djelovanje te tada AT brzo neutralizira trombin, stvarajući stehiometrijski kompleks trombin-antitrombin u kojem trombin ireverzibilno gubi enzimatsku aktivnost ${ }^{7,9}$. Osim antikoagulacijske, ima i protupalnu ulogu ${ }^{7}$. Gen za AT nalazi se na p kraku 1. kromosoma i dosad je opisano više od 80 različitih genskih varijanti ${ }^{4}$. Nasljeđuje se autosomno dominantno, muškarci i žene jednako su pogođeni i nema rasne ili etničke sklonosti nasljeđivanju ${ }^{7}$. Prevalencija u općoj populaciji varira u literaturi, najčešće u širokom rasponu od 1 : 600, pa do $1: 5000$, što je posljedica vrlo različite metodologije određivanja ovog deficita u različitim studijama ${ }^{10}$. Postoje različiti podtipovi deficijencija AT-a i svi imaju u podlozi funkcionalne defekte ili niske razine AT-a u plaz$\mathrm{mi}^{8}$.

\section{Tip I - kvantitativni manjak antitrombina}

Ovaj je tip posljedica smanjene sinteze biološki aktivnog AT-a, pa je antigena i funkcionalna aktivnost AT-a u krvi smanjena. Fiziološki značaj AT-a najbolje pokazuje rijetka, ali neizbježna intrauterina smrt $u$ homozigota za ovaj tip deficijencije AT-a ${ }^{9}$. Tu tvrdnju podupire i smrtonosni fenotip koji se opaža kod AT-knockout miševa ${ }^{8,9}$. U heterozigota vrijednosti AT-a smanjene su za oko $50 \%$ u odnosu na zdrave pojedince.

\section{Tip II - kvalitativni manjak antitrombina}

Tip II nedostatka AT-a rezultat je diskretnog molekularnog defekta. Dok je u ovom tipu bolesti imunološka aktivnost AT-a normalna, funkcionalna aktivnost AT-a značajno je smanjena, što dovodi do rizika od tromboze ${ }^{4}$. Tip II može se dodatno klasificirati u tri tipa, ovisno o mutacijama i prema rezultatima različitih testova ${ }^{7}$. Nedostatak AT-a dovodi i do 10 puta većeg rizika od venskih tromboembolija (VTE) negoli ga ima zdrava populacija ${ }^{4,8}$. lako su zabilježeni neki slučajevi arterijske tromboembolije u osoba s nedostatkom AT-a, ta je povezanost mnogo slabija i sam nedostatak AT-a rijetko je povezan s moždanim udarom ${ }^{7,11}$. Tromboembolijske epizode su rijetke prije puberteta u osoba s nedostatkom AT-a, štoviše neuobi- 
čajeni su incidenti tijekom prva dva desetljeća života ${ }^{4,7}$. VTE se počinju pojavljivati nakon puberteta, pri čemu se rizik značajno povećava s dobi ${ }^{4}$. $U$ dobi od 50 godina, oko $50 \%$ osoba s deficijencijom AT-a imalo je epizodu VTE-a ${ }^{7}$. VTE se karakteristično javlja kao DVT nogu i ruku i PTE, ali se može pojaviti i na neuobičajenim mjestima, kao što su venski sinusi, mezenterične, portalna, jetrene, bubrežne i retinalne vene. Oko 60 \% VTE-a u pacijenata s nedostatkom AT-a je spontano i nepovezano s drugim čimbenicima, a $40 \%$ je povezano s prolaznim čimbenicima rizika koji su pospješili nastanak tromboza ${ }^{7}$. S obzirom na to da neki stečeni čimbenici dodatno povećavaju rizik za VTE, potrebno je obratiti pozornost i na takva stanja ${ }^{12}$.

\section{Nasljedni manjak proteina C}

PC je izolirao iz goveđe plazme Johan Stenflo 1976. godine, dok je funkcija samog proteina ostala neprepoznata do nekoliko godina kasnije, kada Griffin i suradnici u obiteljskoj studiji venske tromboze kao mogući uzrok bolesti navode nisku razinu ovog proteina u plazmi ${ }^{13}$. Godinu dana kasnije, 1983., Broekman i suradnici kao uzrok trombofilije $u$ tri nizozemske obitelji utvrđuju manjak PC-a i zaključuju da se radi o autosomno dominantnom nasljeđivanju s promjenljivom ekspresivnošću ${ }^{4}$. PC je serinska proteaza ovisna o vitaminu $\mathrm{K}$ i sintetizira se $\mathrm{u}$ jetri. Krvlju cirkulira inaktivan ${ }^{14}$. Primarni učinak aktiviranog PC-a (APC) je da uz prisutnost kofaktora PS i kalcijevih iona proteolitičkom reakcijom koja zahtijeva fosfolipide na površini aktiviranih trombocita i endotelnih stanica inaktivira koagulacijske faktore $\mathrm{V}$ i VIII. Ovo zauzvrat sprječava daljnju generaciju trombina i konačno smanjuje stvaranje fibrinskog ugruška, a uz to povećava fibrinolizu putem smanjene aktivacije inhibitora fibrinolize ${ }^{15}$. APC također djeluje u regulaciji upale ${ }^{8}$. Uzrok nedostatka proteina $\mathrm{C}$ je mutacija u genu PROC koji se nalazi na 2. kromosomu4 ${ }^{4}$. Postoje dva obrasca nasljeđivanja bolesti. Blaži heterozigotni oblik nedostatka PC-a nasljeđuje se autosomno-dominantno. Teški oblici nasljeđuju se autosomno recesivnim načinom $^{14,16}$. Učestalost asimptomatskog oblika je 1 : 200 - 500 ljudi u općoj populaciji, dok se incidencija klinički značajnog nedostatka PC-a procjenjuje na 1 : 20 000, a teškog nedostatka PC-a na oko
1 : 500000 - 750000 ljudi u općoj populaciji ${ }^{14,16}$. Nedostatak PC-a zahvaća muškarce i žene u podjednakom broju i ne pokazuje rasne i etičke predilekcije ${ }^{14}$.

\section{Autosomno-dominantni manjak proteina $C$}

Dva glavna tipa autosomno-dominantnog oblika opisana su pomoću imunoloških i funkcionalnih testova s više od 160 različitih genskih abnormalnosti ${ }^{17}$.

Tip I - kvantitativni oblik autosomno-dominantnog manjka proteina $C$

Najčešći je oblik bolesti, pacijenti su heterozigoti, imaju smanjenu koncentraciju plazmatskog PC za približno $50 \%{ }^{4}$. S obzirom na količinski manjak PC-a bolest je obilježena antigenim i funkcionalnim deficitom ovog proteina. Urođeni manjak PC-a dovodi do 7 puta veće vjerojatnosti trombotskih incidenata ${ }^{18}$.

Tip II - kvalitativni oblik autosomno-dominantnog manjka proteina $C$

U ovom tipu nedostatka PC-a postoji normalna razina plazmatskog $\mathrm{PC}$-a, ali sa smanjenom funkcionalnom aktivnošću. U ovom su poremećaju identificirane različite točkaste mutacije koje utječu samo na funkciju proteina ${ }^{4}$. Klinički fenotip jednostavnog heterozigotnog nedostatka PC-a može se kretati od asimptomatske do snažne trombofilne predispozicije $s$ recidivnim trombozama. Pored DVT-a i PTE-a, pacijenti s heterozigotnim nedostatkom PC-a mogu razviti ishemijski arterijski moždani udar, mezenterijske tromboze i trombozu u trudnoći ${ }^{14,15}$.

\section{Autosomno-recesivni manjak proteina C}

Homozigotni ili složeni heterozigotni oblik pojavljuje se iznimno rijetko, a razina PC-a u plazmi je ispod $1 \%{ }^{19}$. Teški kongenitalni nedostatak PC-a manifestira se ozbiljnom trombozom, sistemskim simptomima, ponekad odmah nakon rođenja i purpurom fulminans $(P F)^{19}$. PF je progresivno i životno ugrožavajuće stanje koje se manifestira pojavom hemoragijskih nekroza kože i diseminiranom intravaskularnom koagulacijom ${ }^{20}$. Mogu se pojaviti i gangrene kao posljedica stvaranja mikrotromba. Prognoza je nepovoljna čak i kada se pacijent liječi svježe smrznutom plazmom, antikoagulansima i koncentratima pročišćenog PC-a ${ }^{19}$. 


\section{Nasljedni nedostatak proteina $\mathbf{S}$}

Ubrzo nakon izvješća o PC-u, Richard DiScipio, student iz Seattlea, otkrio je još jedan protein koji ovisi o vitaminu K, koji je nazvan PS, a nekoliko godina kasnije Walker je pokazao da PS funkcionira kao kofaktor APC-a u degradaciji faktora VIII, da bi 1984. godine Comp i Esmon opisali dvojicu braće kao prve pacijente $s$ trombozom nastalom zbog urođenog nedostatka PS-a ${ }^{21}$. Geni za PSPROS 1 i PROS 2 nalaze se na 3. kromosomu ${ }^{13}$. PS

Cijena testova za otkrivanje ovih nasljednih poremećaja je značajna, postoji psihološki utjecaj rezultata testiranja na pojedinca, a još uvijek je donekle otvoreno pitanje koga testirati i što eventualna informacija o postojanju nasljedne trombofilije zaista mijenja u medicinskom pristupu i prognozi pacijenta.

se poglavito stvara u jetri, ali i u nekim specifičnim staničnima tipovima (osteoblastima, megakariocitima, endotelnim i glatkim mišićnim stanicama). Do danas su otkrivene brojne mutacije ovih gena koje mogu uzrokovati poremećaj ${ }^{22}$. Postoje 3 tipa nedostatka PS-a.

\section{Tip I nedostatka proteina S}

Klasični tip nedostatka PS-a povezan je sa smanjenom razinom ukupnog antigena (otprilike $50 \%$ od normalne vrijednosti) i posljedično tome sa značajno smanjenim funkcijama proteina ${ }^{4}$.

\section{Tip II nedostatka proteina $S$}

Ovu vrsta nedostatka PS-a karakterizira normalna ukupna i slobodna količina proteina, ali njegova smanjena funkcionalnost ${ }^{4}$. Tip II je rjeđi i dijagnosticira se u oko $5 \%$ slučajeva deficijencije PS-a ${ }^{6}$.

\section{Tip III nedostatka proteina S (tip IIa)}

U ovom tipu nedostatka normalna je ukupna količina proteina, ali je smanjena slobodna frakcija PS-a, pa je njegova fiziološka aktivnost obično manja od $40 \%{ }^{4}$.

Heterozigotni nedostatak PS-a povezan je s 5 11,5 puta povećanim rizikom od VTE-a u obiteljskim ispitivanjima, ali to se nije moglo potvrditi u svim studijama6. Tromboembolijski događaj obično se manifestira u odrasloj dobi. Većina simpto- matskih pacijenata imala je različite kombinacije DVT-a (74\%), superficijalnog tromboflebitisa (72\%) i PTE (38\%), bilo sukcesivno ili istodobno. U više slučajeva pronađena je tromboza na neobičnim mjestima, kao što su aksilarne, mezenterijske i cerebralne vene. Starost kod prvog tromboembolijskog događaja kretala se od 15 do 68 godina (srednja vrijednost 28 godina), a u dobi od 35 godina vjerojatnost da još uvijek nema tromboze bila je samo $32 \%{ }^{23}$. Rjeđe, klinička manifestacija ovog defekta može biti varfarinom inducirana nekroze kože (VINK). VINK je rijetka komplikacija koja se javlja u pojedinaca liječenih varfarinskim preparatima koji imaju trombofilnu sklonost i osim s defektima PS-a povezana je i s manjkom PC-a i AT-a ${ }^{24}$. Kada je defekt PS-a prisutan u homozigotnom obliku ili zajedno s drugim urođenim defektima prezentira se već u neonatalnoj dobi kao PF4.

\section{Faktor V Leiden}

Povijest otkrića faktora V Leiden (FVL) i otpornosti na APC započinje u 90-im godinama prošlog stoljeća, kada je Dahlback sa suradnicima u nekoliko obitelji sa sklonošću trombozama identificirao nasljedni loš odgovor na antikoagulacijski učinak APC-a ${ }^{25}$. Nedugo zatim Bertina i suradnici prepoznaju mutaciju koja dovodi do ovog stanja te prvi opisuju defekt gena faktora $V$ koji ga čini neosjetljivim na inaktivaciju APC-a ${ }^{26}$. Najčešća mutacija $u$ genu za faktor $V$ naziva se Leiden (FVL). Daljnje mehanizme ovog poremećaja dodatno razjašnjava Kalafaris sa suradnicima ${ }^{27}$. FVL je karakteriziran specifičnom zamjenom gvanina $\mathrm{S}$ adeninom na nukleotidu 1691 gena za faktor $\mathrm{V}$ koji dovodi do supstitucije aminokiselina glutamina za arginin na mjestu za cijepanje Arg506. FVL je karakteriziran zamjenom gvanina $s$ adeninom na 1691. položaju nukleotida u genu za faktor $V$, što dovodi do supstitucije aminokiselina glutamin za arginin na 506. položaju u redoslijedu aminokiselina, ujedno i mjestu za cijepanje. Zbog tih promjena APC više ne prepoznaje ovo specifično mjesto te dolazi do izostanka cijepanja faktora Va, što u konačnici dovodi do njegove povećane aktivnosti i povećanog nakupljanja trombina. Faktor $\mathrm{V}$ koji u fiziološkim uvjetima biva pocijepan na poziciji 506 također fiziološki funkcionira 
kao kofaktor (zajedno s PS-om) za APC-posredovanu inaktivaciju faktora VIIIa ${ }^{28}$. Smatra se da je rezistencija na APC najčešći nasljedni nedostatak koji se može identificirati u pacijenata s DVT-om. FVL je najčešći čimbenik genetičkog rizika za VTE, koji se nalazi u 20 - $25 \%$ pacijenata s VTE-om i $50 \%$ pacijenata s obiteljskom trombofilijom ${ }^{4,6,28}$. Heterozigotnost za FVL javlja se u $3-5 \%$ bijele populacije, dok je učestalost u crne populacije i Azijata manja. Učestalost homozigotnosti za faktor $\mathrm{V}$ Leiden u bijeloj populaciji je približno 1 na $5000^{29}$. Nasljeđivanje ovog poremećaja je autosomno-dominantno. Heterozigoti imaju oko 5 puta veći rizik za VTE, a homozigoti znatno viši rizik (i do 80 puta) ${ }^{28}$. Na pojavu tromboembolijskih incidenata kod nosioca mutacije FVL utječe broj zahvaćenih alela, istodobno postojanje drugih genetičkih i stečenih trombofilnih poremećaja te prisutnost okolišnih faktora rizika, a PTE kao posljedica DVT-a je u ovom poremećaju manje česta negoli u drugim nasljednim trombofilijama ${ }^{28}$.

\section{Protrombinske varijante}

Druga najčešća, no ujedno i među posljednjim otkrivena, genska abnormalnost koja uzrokuje nasljednu trombofiliju je mutacija protrombina ${ }^{4}$. Otkrili su je Poort i suradnika. Naime, 1996. godine Poort i suradnici su genetičkom analizom protrombina u pojedinaca iz 28 obitelji s venskom trombozom i 100 normalnih odraslih otkrili promjenu u genetičkom kodu koja uzrokuje da tijelo proizvodi previše protrombina. Ta promjena uzrokovana je zamjenom gvanina adeninom na nukleotidu 20210 u genu za protrombin koja rezultira povećanim generiranjem navedenog proteina u plazmi. Njihov zaključak je da povišena koncentracija protrombina pogoduje nepotrebnom i neadekvatnom zgrušavanju krvi i nastanku tromboza, čime prisutnost mutacije 20210A dovodi do povišenih koncentracija protrombina te postaje rizični faktor za trombozu ${ }^{30}$. Protrombin ili koagulacijski faktor II je protein u plazmi koji je potreban za normalno formiranje fibrina. Manjak protrombina dovodi do sklonosti krvarenju, dok se akumulacija protrombina povezuje sa sklonošću trombozama ${ }^{31}$. Trombofilija povezana s protrombinom nasljeđuje se na autosomno-dominantan način. Prevalencija heterozigota za 20210A u bijeloj rasi ovisi o geografskoj distribuciji (npr. veća je u Španjolskoj) i za područje Europe iznosi 0.7 do $6.5 \%$, a rizik za DVT je oko 2 - 6 puta povećan ${ }^{4}$. Heterozigoti imaju oko $30 \%$ veću razinu protrombina u plazmi u odnosu na zdrave pojedince ${ }^{31}$. Homozigotni oblik smatra se neuobičajenim i ima prevalenciju od otprilike $1: 10000 \mathrm{~s}$ rizikom za DVT i do 30 puta većim od zdravih pojedinaca ${ }^{31}$. Mutacija protrombina 20210A podjednako je česta u muškaraca i žena ${ }^{31}$. Novije studije ukazuju da je ova mutacija sama po sebi zapravo slab do srednje snažan čimbenik rizika za VTE te da inducira VTE uglavnom u kombinaciji s drugim stečenim ili nasljednim faktorima rizika. Danas prevladava mišljenje da samo homozigoti za navedenu mutaciju imaju značajno povećani rizik od VTE-a, te se u njih približno $40 \%$ svih događaja VTE javlja spontano ${ }^{32}$. Suprotno prvotnim razmišljanjima da je mutacija protrombina povećan rizik za razvoj arterijske tromboze, daljnja istraživanja to nisu jasno potvrdila ${ }^{32-34}$.

\section{RASPRAVA}

Tromboembolijska bolest zauzima značajan udio u pobolu i pomoru stanovništva, pa tako i mlađih osoba, a nasljedna trombofilija kao jedan od nedovoljno istraženih predisponirajućih čimbenika koji dovode do tromboembolijskih incidenata predstavlja velik izazov liječnicima. Genske varijacije poput FVL-a i protrombinske varijante, nedostatak PC-a, PS-a i AT-a povećavaju rizik od razvoja venskog tromboembolizma, no sami poremećaji su karakterizirani varijabilnom ekspresivnošću i nepotpunom penetrabilnošću ${ }^{4,35}$. Uz to sama predispozicija za stvaranje ugrušaka najčešće proizlazi iz interakcije između genetičkih i stečenih čimbenika ${ }^{4,6}$. Važno je napomenuti da postoje različita stanja, primjerice razne bolesti, traume, dugotrajni avionski letovi, dugotrajna nepokretnost ili pak kirurški zahvati (Tablica 1), koja mogu dovesti do tromboze $u$ inače asimptomatskih pojedinaca koji imaju neotkrivenu nasljednu sklonost trombozi ${ }^{4}$. lako se znanje o nasljednim trombofilnim poremećajima stalno povećava, ostaju brojna otvorena pitanja vezana za ovu problematiku te ne postoji opći konsenzus eksperata o različitim modalitetima ove problematike ${ }^{4,6,8}$. U kliničkom pristupu trombofilnim stanjima od naj- 
veće je važnosti minuciozna anamneza (osobna i obiteljska), a od laboratorijske dijagnostike na raspolaganju su različiti funkcionalni, imunološki i genetski testovi ${ }^{36}$.

Cijena testova za otkrivanje ovih nasljednih poremećaja je značajna, postoji psihološki utjecaj rezultata testiranja na pojedinca, a još uvijek je donekle otvoreno pitanje koga testirati i što eventualna informacija o postojanju nasljedne trombofilije zaista mijenja u medicinskom pristupu i prognozi pacijenta ${ }^{37-39}$. Trenutačno prevladava mišljenje da testiranje nasljedne trombofilije obuhvaća dokazivanje nedostatka AT-a, PC-a i PS-a te prisutnost FVL-a i protrombinske varijante $20210 A^{40}$. Danas je poznato da i neki drugi nasljedni čimbenici, kao npr. povišena koncentracija faktora VIII i homocisteina te neki poremećaji lipoproteina i fibrinogena, mogu povećati sklonost tromboembolijskim incidentima ${ }^{4}$. Odgovor na pitanje kada je testiranje opravdano još uvijek nema opće prihvaćen odgovor i mišljenja pojedinih eksperata se donekle razlikuju. Sigurno je da se ovi testovi isuviše često i nekritički koriste bez indikacije (najčešće u slučajevima DVT u starijih pacijenata ili onih u kojih je DVT bila provocirana poznatim tranzitornim rizičnim čimbenicima). Literaturni podaci upućuju na razmatranje testiranja u slučaju pojave neprovociranog (idiopatskog, spontanog) VTE-a u mladih pacijenata (ispod 50. godine) s ili bez pozitivne obiteljske anamneze, rekurentnih neprovociranih tromboza, u slučaju pojave tromboze neobičnih lokalizacija ili pak VINK ili neonatalne $\mathrm{PF}^{41-43}$. Laboratorijsko ispitivanje AT-a, PC-a i PS-a ne smije se raditi za vrijeme akutne faze trombotskog događaja, za vrijeme liječenja antikoagulantnim lijekovima te neposredno nakon prekidanja antikoagulantne terapije ${ }^{44}$. Pacijenti s prirođenom trombofilijom i prvom epizodom VTE-a/PTE-a liječe se kao i svi drugi pacijenti s tromboembolijskim događajima antikoagulantnom terapijom ${ }^{45,46}$. Procjena o duljini antikoagulantne terapije te o tome da hoće li ona biti preporučena trajno strogo je individualna i ovisi o više čimbenika, među kojima su najvažniji sljedeći: je li trombotski događaj bio neprovociran ili provociran, koliko je bila teška klinička slika, kakva je težina i biologija samog nasljednog poremećaja koji je doveo do trombofilije, je li pa- cijent izložen drugim rizičnim čimbenicima za trombozu. Osobama s prirođenom trombofilijom savjetuje se antikoagulantna profilaksa u slučaju izlaganja tranzitornim rizičnim situacijama, kao npr. kirurški zahvati, dugotrajna imobilizacija, dugotrajno putovanje avionom i slično ${ }^{4}$. Također se svima preporučuje izbjegavanje drugih čimbenika koji mogu povećati rizik za trombozu: pušenje cigareta, debljina, visok krvni tlak, uzimanje oralnih kontraceptiva, povišene masnoće u krvi, fizička neaktivnost ${ }^{4}$.

Izjava o sukobu interesa: Autori izjavljuju da ne postoji sukob interesa.

\section{LITERATURA}

1. Prowan D. Singer CRJ, Baglin T, Lilleyman J. Oxford Handbook of Clinical Haematology, $3^{\text {nd }}$ Edition. Oxford University Press, London, 2009;448-538.

2. Rosendaal FR. Venous thrombosis:a multicausal disease. Lancet 1999;353:1167-73.

3. Lane DA, Mannuccini PM, Bauer KA, Bertina RM, Bochkov NP, Boulyjekov $V$ et al. Inherited thrombophilia: Part 1. throm Haemost 1996;76:651-62.

4. Khan S, Dickerman JD. Hereditary thrombophilia. Thrombosis Journal. 2006;4:15.

5. Egeberg 0 . Inherited antithrombin deficiency causing thrombophilia. Thromb Diath Haemorrh 1965;13:516-30.

6. Koenderman JS, Reitsma PH. Inherited Thrombophilia: Past, Present, and Future Research [Internet]. 2011; Available from: https://www.intechopen.com/books/ thrombophilia/inherited-thrombophilia-past-presentand-future-research

7. Patnaik MM, Moll S. Inherited antithrombin deficiency: a review. Haemophilia 2008;14: 1229-39.

8. Dahlbäck B. Advances in understanding pathogenic mechanisms of thrombophilic disorders. Blood 2008;112:19-27.

9. Negreva M, Georgiev S, Prodanova K. Nikolova J. Early changes in the antithrombin and thrombin-antithrombin complex in patients with paroxysmal atrial fibrillation. Cardiol Res 2016;7:89-94.

10. Tait RC, Walker ID, Perry DJ,Islam SI, Daly E, McCall F et al. Prevalence of antithrombin deficiency in the healthy population. Br J Haematol 1994; 87: 106-12.

11. Soare AM, Popa C. Deficiencies of proteins C, S and Antithrombin and factor $\mathrm{V}$ Leiden and the risk of ischemic strokes. J Med Life 2010;3:235-38.

12. Husar D, Đelmiš J. Trombofilija i njezin utjecaj na ishod trudnoće. Gynaecol Perinatol 2008;17:150-56.

13. Griffin JH, Evatt B, Zimmerman TS, Kleiss AJ, Wideman C. Deficiency of protein $C$ in congenital thrombotic disease. J Clin Invest 1981;68:1370-3.

14. Goldenberg NA, Manco-Johnson MJ. Protein C deficiency. Haemophilia 2008; 14:1214-21.

15. Dreyfus M, Ladouzi A, Chambost H, Gruel Y, Tardy B, Ffrench $P$ et al. Treatment of inherited protein $C$ deficiency by replacement therapy with the French purified plasma-derived protein C concentrate. Vox Sanguinis 2007;93:233-40. 
16. Kang S. Protein C deficiency. NORD (National Organization for Rare Disorders). [Internet].2016; Available from: https://rarediseases.org/rare-diseases/protein-c-deficiency/

17. Reitsma PH, Bernardi F, Doig RG, Gandrille S, Greengard JS, Ireland $\mathrm{H}$ et al.: Protein $\mathrm{C}$ deficiency: $\mathrm{A}$ database of mutations, 1995 update. Thromb Haemost 1995;73:876.

18. Angelillo-Scherrer A, Nagler M. Thrombophilieabklärung: Update, Guidelines in den Grauzonen. Therapeutische Umschau 2016;73:626-34.

19. Tairaku S, Taniguchi-Ikeda M, Okazaki M, Noguchi Y, Nakamachi J, Mori T et al. Prenatal genetic testing for familial severe congenital protein $\mathrm{C}$ deficiency. Human Genome Variation 2015;2:15017.

20. Mukherjee D, Pal P, Kundu R. Purpura Fulminans due to acquired protein C deficiency. Indian J Dermatol 2015;60:637.

21. Comp PC, Nixon RR, Cooper MR, Esmon CT. Familial protein $\mathrm{S}$ deficiency is associated with recurrent thrombosis. J Clin Invest 1984;74:2082-8.

22. Gandrille S, Borgel D, Sala N, Espinosa-Parrilla Y, Simmonds $\mathrm{R}$, Rezende $\mathrm{S}$ et al. Protein $\mathrm{S}$ deficiency: a database of mutations--summary of the first update. Thromb Haemost 2000;84:918.

23. Engesser L, Broekmans AW, Briet E, Brommer EJ, Bertina $\mathrm{RM}$. Hereditary protein $S$ deficiency: clinical manifestations. Ann Intern Med 1987;106:677-82.

24. Kakagia DD, Papanas N, Karadimas E, Polychonidis A. Warfarin induced skin necrosiss. Ann Dermatol 2014;26:96-8.

25. Dahlback B, Carlsson M, Svensson PJ. Familial thrombophilia due to a previously unrecognized mechanism characterized by poor anticoagulant response to activated protein C: prediction of a cofactor to activated protein C. Proc Natl Acad Sci USA 1993;90:1004-8.

26. Bertina RM, Koeleman BPC, Koster T. Mutation in blood coagulation factor $\mathrm{V}$ associated with resistance to activated protein C. Nature 1994;369:64-7.

27. Kalafatis M, Bertina RM, Rand MD, Mann KG: Characterization of the molecular defect in factor VR506Q. J Biol Chem 1995;270:4053-7.

28. Kujovich JL. Factor V Leiden thrombophilia. Genetics in Medicine 2011;1:16.

29. Van Cott EM, Khor B, Zehnder JL. Factor V Leiden. Am J Hematol 2016;91:46-9.

30. Poort SR, Rosendaal FR, Reitsma PH, Bertina RM. A common genetic variation in the $3^{\prime}$-untranslated region of the prothrombin gene is associated with elevated plasma prothrombin levels and an increase in venous thrombosis. Blood 1996;15;88:3698-703.

31. Varga EA, Moll S. Prothrombin 20210 Mutation (Factor II Mutation). Circulation 2004;110:15-8.
32. Bank I, Libourel EJ, Middeldorp S; van Pampus ECM, Koopman MMW, Hamulyák K et al. Prothrombin 20210A mutation: a mild risk factor for venous thromboembolism but not for arterial thrombotic disease and pregnancy-related complications in a family study. Arch Intern Med 2004;164:1932-37.

33. Butt C, Zheng H, Randell E, Robb D, Parfrey P, Xie Y. Combined carrier status of prothrombin 20210A and factor XIII-A Leu34 alleles as a strong risk factor for myocardial infarction: evidence of a gene-gene interaction. Blood 2003;101;3037-41.

34. Kujovich JL. Prothrombin-Related Thrombophilia. [Internet]. 2006; In: Pagon RA, Adam MP, Ardinger HH, et al (Ed) GeneReviews, Seattle: University of Washington. Available from: https://www.ncbi.nlm.nih.gov/books/ NBK1148/

35. Van Sluis GL, Sohne M, El Kheir DY, Tanck MW, Gerdes VEA, Buller HR. Family history and inherited thrombophilia. J Thromb Haemost 2006;4:2182-7.

36. Linnemann B, Hart C: Laboratory Diagnosis in Thrombophilia. Haemostaseologie 2019; 39:49-61. Linnemann B, Hart C: Laboratory Diagnosis in Thrombophilia. Haemostaseologie 2019; 39:49-61.

37. Stegnar M. Thrombophilia screening-at the right time, for the right patient, with a good reason. Clin Chem Lab Med 2010;48:105-13.

38. Middeldorp S. Evidence-based approach to thrombophilia testing. J Thromb Thrombolysis 2011;31:275-81.

39. Pruthi RK. Optimal Utilization of Thrombophilia Testing. Int J Lab Hematol 2017; 39:104-10.

40. Middeldorp S, Coppens M. Evolution of thrombophilia testing. Hematologia 2013;17:26-37.

41. Mitic $\mathrm{G}$. Integrative approach to the patient with thrombophilia. J Med Biochem 2014;33:47-57.

42. Conors JM. Thrombophilia Testing and Venous Thrombosis. N Eng/ J Med 2017;377:1177-87.

43. Colucci G, Tsakris DA. Thrombophilia Screening: Universal, Selected, or Neither? Clin Appl Thromb Hemost 2017;23:893-9.

44. Stevens SM, Woller SC, Bauer KA, Kasthuri R, Cushman $M$, Streiff $M$ et al. Guidance for the evaluation and treatment of hereditary and acquired thrombophilia. J Thromb Thrombolysis 2016;41:154-64.

45. Ashraf N, Visweshwar N, Jaglal M, Sokol L, Laber D. Evolving Paradigm in Thrombophilia Screening. Blood Coagul Fibrinolysis 2019; 30:249-52.

46. Alameddine R, Nassabein R, Le Gal G, Sie P, Mullier F, Blais N. Diagnosis and Management of Congenital Thrombophilia in ehe Era of Direct Oral Anticoagulants. Thromb Res 2020; 185:72-77. 